\title{
Assessment of Hydraulic Parameters and Protection Zones of Catchment Aquifers for Water Supply Network in Ndé Division, West-Cameroon (Central Africa)
}

\author{
Roger Feumba*, Kemgang Dongmo Tchouta, Jean Ghislain Tabué Youmbi, \\ Valentin Yvan Emmanuel Mvondo, Depesquidoux I. Tchaptchet Tchato, \\ Benjamin Ngounou Ngatcha
}

University of Yaoundé I, Yaoundé, Cameroon

Email: ^roger.feumba@facsciences-uyl.cm,ngatchangou@yahoo.fr, simsonkems@yahoo.fr, tabueley@yahoo.fr

How to cite this paper: Feumba, R., Kemgang Dongmo Tchouta, Tabué Youmbi, J.G., Mvondo, V.Y.E., Tchaptchet Tchato, D.I. and Ngounou Nagtcha, B. (2021) Assessment of Hydraulic Parameters and Protection Zones of Catchment Aquifers for Water Supply Network in Ndé Division, West-Cameroon (Central Africa). Journal of Water Resource and Protection, 13, 478-497.

https://doi.org/10.4236/jwarp.2021.137028

Received: June 12, 2021

Accepted: July 13, 2021

Published: July 16, 2021

Copyright ( 2021 by author(s) and Scientific Research Publishing Inc. This work is licensed under the Creative Commons Attribution International License (CC BY 4.0)

http://creativecommons.org/licenses/by/4.0/ (c) (i) Open Access

\begin{abstract}
Ndé Division in West-Cameroon is facing with water supply although many attempts of restoring existing SCANWATER facilities by Bangangté Municipality. In order to address the issue, we assess the exploitable pumping flow rate of catchment aquifers and its hydraulic properties by using Jacob and Theis method, and define protection zones with Hoffman and Lillich method. It emerges that the hydraulic conductivity of aquifer is in the order of $10^{-4}$ $\mathrm{m} / \mathrm{sec}$, transmissivity varies from $10^{-4}$ to $10^{-6} \mathrm{~m}^{2} / \mathrm{sec}$. Aquifer pumping flow rate $(Q)$ varies between 1.5 and $10.5 \mathrm{~m}^{3} / \mathrm{h}$. In volcanic rocks, aquifer is more productive $\left(4.5 \leq Q \leq 10.5 \mathrm{~m}^{3} / \mathrm{h}\right)$. Transfer time of pollutants to aquifer varies from 3 to 56 days depending on rock-types and groundwater slope (0.03 $0.13 \mathrm{~m} / \mathrm{m}$ ). Furthermore, $113,624 \mathrm{~m}$ and $1123 \mathrm{~m}$ are radius to be implemented for a better protection of groundwater against any form of pollutant.
\end{abstract}

\section{Keywords}

Pumping Tests, Aquifer Properties, Groundwater Protection, Ndé Division, West-Cameroon (Central Africa)

\section{Introduction and Geological Background}

\subsection{Introduction}

Groundwater, which is known to account for about $98 \%$ of the world's water needs has the advantage of not being affected easily by natural conditions or otherwise and it is in most cases sufficiently secluded from contaminants perco- 
lating from the surface since the earth's layers act as the natural filter to stop contaminants. This is why the search for groundwater is a viable option in taking on our demand for sufficient and quality water [1]. Hydraulic parameters, especially the hydraulic conductivity and transmissivity, which are usually estimated from pumping test carried out on drilled boreholes [2] [3], are of great interest in the hydraulic characterisation of aquifer systems as it enables to design exploitation and management strategies, especially in lithological heterogeneous aquifers [4]. Transmissivity of aquifer systems is the main hydraulic parameter controlling long term drawdowns and is therefore important for development and management of groundwater exploitation [4].

Increasing population rate and, water usefulness (drinking, hygiene, sanitation and agricultural activities [5] have resulted in high demand in water in town as well as in rural areas. During years $70-80$, Cameroon through Danish technical assistance built 365 water supply networks in 335 villages spread over 8 regions with 70 in West region, which functioned properly for 10 years, to meet the lack of public water supply networks in rural areas [6]. Ndé Division was among the selected area where facilities called "SCANWATER" were built in 9 villages (Toukouop, Batchingou, Sanki, Bandiangseu, Bangoulap, Bahouoc, Bangoua, Kamna and Bamena). Despite these water facilities, population is still facing to drinking water access, although many attempts of rehabilitation (three reasons motivated the restoration of these water supply networks): 1) All equipments of these water supply networks are still existing but poorly maintained due to lack of trained technician during project implementation ten years ago; 2) The privilege has been focused primarily on defective water supply network and 3) The geological context of the rural city of Bangangté and the former productivity of the catchment borehole because only $33 \%$ of them are running and hence (in 2020, three villages amongst the nine, have their network still nonfunctional, Kamna, Bangoua and Bahouoc) drinking water access rate remains low $(<15 \%)$. This has led population to adopt old practices of hydraulic drilling such as boreholes, wells and springs, which is prone to contamination by pollutants. Furthermore, Ndé division is located at the southern continental segment of Cameroon Volcanic Line (CVL) where aquifers are complexes as far as productivity and sustainability are concerned [6]. Except the work of [6] carried out at regional scale, which showed a bi-layer system (an unconfined aquifer, usually between 5 - $20 \mathrm{~m}$ of depth and generally used for wells, and a discontinuous fissured aquifer of the basement, usually greater than $20 \mathrm{~m}$ of depth is used for boreholes) and those about water quality and vulnerability [7] [8] [9] [10] [11], the issue of the productivity of these aquifers has not yet been addressed in the study area. This study aims to assess hydraulic parameters and intrinsic pumping rate of the basement aquifers as they are critical to identify area of potential water resources [12] [13] and are helpful for defining protection zones.

\subsection{Geological Background}

Ndé division is made up of a pan-African basement that belongs to the central 
domain of the Central Africa Fold Belt [14], formed by 650 - 580 Ma collision between the Congo-Sao Francisco craton, West African Congo and Saharan metacraton [15]. It consists of variably deformed $580 \mathrm{Ma}$ post-collisional, metaluminous to peraluminous, high $\mathrm{K}$ calc-alkaline to shoshonite affinity I type granitoids [16], originated from the partial melting of metasomatized sub continental lithospheric mantle with little crustal contamination and emplaced at the waning stage of the Central Africa Fold Belt in the 635 - $645 \mathrm{Ma}$ (U-Pb age, [17]), metagranodiorites and metaleucogranites associated to migmatitic gneiss. In the study area, these pan-African rocks are cross cut by cretaceous tholeiitic basalts [18] whose emplacement into in the upper crust was controlled by Riedel's fracture kinematic model [19]. These pan-African rocks are partially covered by tertiary basalts that formed the eastern edge of the western Cameroon Highlands located in the NE trending southern continental segment of the CVL that stretches from the Annobon Island to Lake Chad [20]. These tertiary basalts occur as prismatic columnar lava flow at a mean altitude of $1400 \mathrm{~m}$ and dominantly consist of 3 - $14 \mathrm{Ma}$ alkaline and 36 - $47 \mathrm{Ma}$ transitional basalts [21] [22] [23] [24]. Both basalts are the product of the interaction between mantle upwelling and sublithospheric continental during a lithospheric extensional tectonic setting [22] [25].

The studied area has recorded a polyphase deformation characterized by an early D1 deformational phase of thrust tectonics constrained at $\geq 602 \mathrm{Ma}$ and is defined by subhorizontal flat lying foliation exposed in the migmatitic gneiss xenolith [17]. This early structures are transposed by NE trending transcurrent tectonics [17] that controlled the 580 Ma post-collisional monzosyenites comlexe emplace at the waning stage of the pan-African event that formed the Central Africa Fold Belt [16].

Related to this literature review, the whole data will be discussed to ensure the availability of underground water able to supply water network to be rehabilitated and to prevent any pollutants in the long term.

\section{Study Site and Methods}

\subsection{Location of the Study Area}

The studied area is located in Ndé division, between latitudes $5^{\circ} 0^{\prime} 0^{\prime \prime}-5^{\circ} 15^{\prime} 36^{\prime \prime} \mathrm{N}$ and longitude $10^{\circ} 23^{\prime} 24^{\prime \prime}-10^{\circ} 38^{\prime} 6^{\prime \prime} \mathrm{E}$, which covers an area of $800 \mathrm{~km}^{2}$ and around 92,035 inhabitants in 2005 [26] (Figure 1).

The soils are essentially ferralitic and developed on both basic and acid rocks. Soils originated from basalt (basic rock) display very clayey texture, ensuring good water retention capacity and a mineralogical composition made up of large quantities of iron hydroxide, gibbsite and kaolinite. With a $\mathrm{pH}$ varying from 4.7 to 5.6 on the surface (thickness) and from 5.5 to 6.5 in depth (thickness), they are rich in organic matter, poor in magnesium, potassium and phosphorus. Their organic matter content is $5 \%$ by surface and their essential constituents are gibbsite and goethite [29]. 


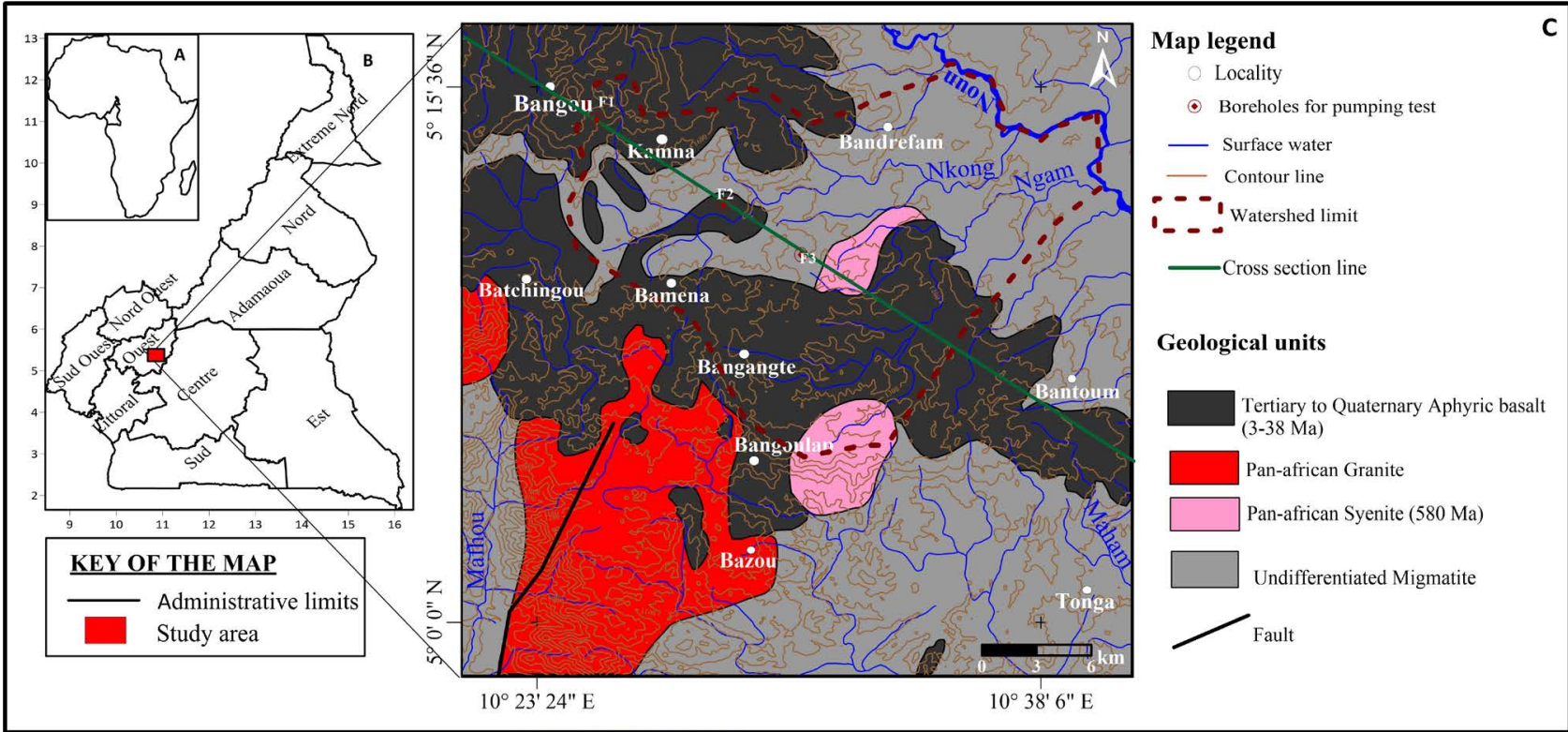

Figure 1. Location (Cameroon in Africa (A) the West region in Cameroon (B)) and overview map of the geological settings of study area (C). The geological map of the study area was simplified from [27] and [28].

\subsection{Methods}

\subsubsection{Data Collection}

Rainfalls data between 1951 and 2016, temperatures and water table measurements (in September 2019 in 66 boreholes and 166 wells) used in this study, were obtained from the Department of Agriculture and Rural Development of Ndé Division supplemented by water table measurements carried out in February 2020 (in 66 boreholes, 84 wells and 33 springs) in order to describe climatic trend and understand groundwater flow.

The estimation of the intrinsic pumping rates and hydrodynamic parameters was carried out by pumping tests in the boreholes which previously supplied SCANWATER. These boreholes were chosen to take into account different geological formations of the study area (that are of Kamna (F1) (volcanic formations), Lah-Gwi (F2) (volcanic formations) and Bandiangseu (F3) (metamorphic formations) to identify the most productive aquifers.

For each pumping test, measurements of the water table were carried out the day before. On each borehole, a curve of the evolution of the water level is drawn and makes it possible to estimate the trend of the piezometric variations. Once these variations have been extrapolated, the next day the step tests are started to determine the pumping rate for the long-term pumping test. Three steps are carried out at each borehole. Each step lasts two hours and is separated from the next step by an equal duration. The pumping test lasted 12 hours and the recovery, an equal time.

A discontinuous, three-steps pumping test were performed on the boreholes of Kamna and Lah-Gwi. The measurements of drawdown of the three steps were also monitored at an equal time for the recovery. Long-term pumping test (12 hours) began immediately at the end of the third step in order to impose a steady 
state drawdown. It took place at a constant pumping rate.

At Badiangseu, a three-steps pumping test has been continuously performed on the borehole. The measurements of drawdown of the three-steps were also monitored at an equal time for the recovery which was only followed at the end of the third step. Pumping test of 12 hours continuously started when the initial water level was obtained in the borehole. It operated at a very varying pumping rate.

For the Kamna borehole, the recovery is more or less slow than the pumping phase because, in 2 hours of pumping, when the drawdown is $4.64 \mathrm{~m}$, we have a recovery at equal time which is $3.58 \mathrm{~m}$. For the Lah-Gwi borehole, the recovery is slow than the drawdown because, in 2 hours of pumping, when drawdown is $3.21 \mathrm{~m}$, we have a recovery at equal time which is $1.10 \mathrm{~m}$.

At Badiangseu, the recovery is very fast because, in 6 hours of continuous pumping, for a drawdown of $28.2 \mathrm{~m}$, we have recovery in 5 minutes of $25.85 \mathrm{~m}$. After this period of time, the recovery becomes slow and returns to the initial water table of $1 \mathrm{~m}$ after 4 hours and 30 minutes that is a total recovery of $27.2 \mathrm{~m}$. The drawdowns in aquifer are no longer observed around 29 meters where the backflow occurs in spurts from 30 seconds intervals to 10 seconds at a pumping rate of less than $1.5 \mathrm{~m}^{3} / \mathrm{h}$. This interaction between the nearest stream and the water table is observed after 8 hours of pumping and the water becomes very clear from this moment.

\subsubsection{Data Processing}

Global Mapper and Surfer software were used for thematic and numerical cartography (watershed of Nkong-Ngam is the experimental study area) and Excel for data processing (Figure 2).

The processing of all data collected enables to determine the intrinsic pumping rate (critical pumping rate $Q_{c}$ and operating pumping rate $Q_{e x}$ ) by the method of [30] [31] [32] and the hydrodynamic parameters by the methods of [33] [34].

Regarding the water balance, the available rainfall data cover a period of 66 consecutive years (1951-2016). The method of [35] was used to estimate the terms of this water balance (evaporation, runoff and effective infiltration).

In Equation (1), $P(\mathrm{~mm})$ is the average rainfall, $E T R(\mathrm{~mm})$ is the actual evapotranspiration, $I(\mathrm{~mm})$ is the infiltration, $R(\mathrm{~mm})$ is runoff and $\triangle R F U$ is the variation of the useful water reserve under the ground or soil.

$$
P=E T R+I+R \pm \Delta R F U
$$

In Equations (2)-(4), $I$ is the annual average temperature index, $T$ is the average temperature in ${ }^{\circ} \mathrm{C}, I$ is the average monthly temperature index in ${ }^{\circ} \mathrm{C}, F(\lambda)$, a correction factor that varies with the month and $\alpha$, an index depending on $I$ (Equation (5)).

$$
E T P=16 \times\left[\frac{10 T}{I}\right]^{\alpha} \times F(\lambda)
$$



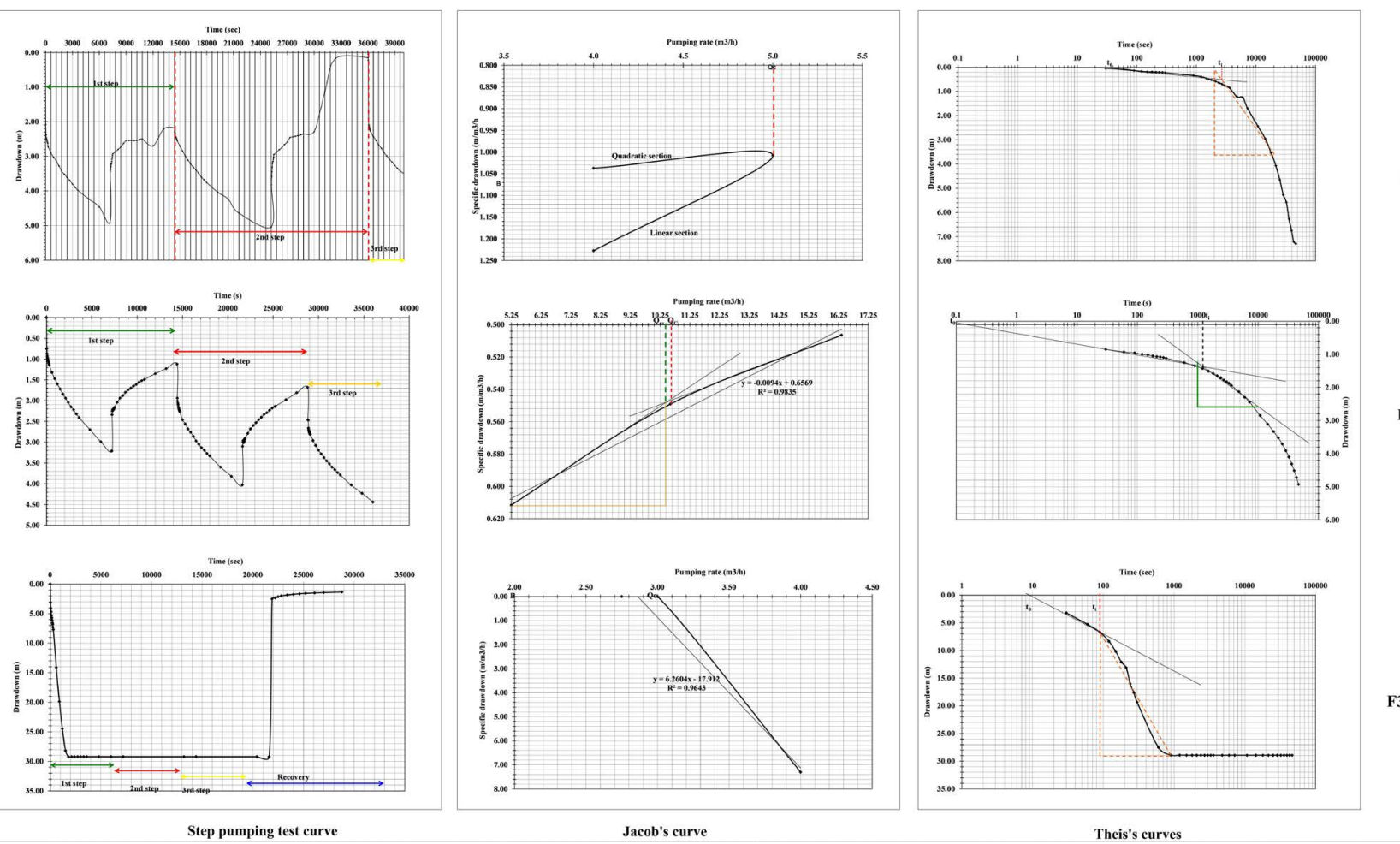

Figure 2. Graphs obtained after the different pumping test in the study area.

$$
\begin{gathered}
i=\left[\frac{T}{5}\right]^{1.514} \\
I=\sum i \\
\alpha=0.492+1.79 \times 10^{-2} I-7.71 \times 10^{-5} I^{2}+6.75 \times 10^{-7} I^{3}
\end{gathered}
$$

For the determination of the hydraulic parameters of discontinuous aquifers (transmissivity $T$ in $\mathrm{m}^{2} / \mathrm{s}$ and hydraulic conductivity $k$ in $\mathrm{m} / \mathrm{s}$ ), the methods developed by [31] [33] [34] were used. Jacob's method is a graphical determination method which results from the logarithmic approximation of the equation of [34]. In Equations (6)-(8), the infinite series or well function $W(u)$ has been truncated according to the second term. $\gamma$ is Euler constant $(0.57772156 \ldots), \Delta$ is the drawdown in each time $t$, expressed in $\mathrm{m}, T$ is the transmissivity expressed in $\mathrm{m}^{2} / \mathrm{s}, S$ is the storage coefficient expressed in percentage, $t$ is the time elapsed since the start of pumping test, expressed in seconds and $Q$ is the pumping rate in $\mathrm{m}^{3} / \mathrm{s}$.

$$
W(u)=\gamma-\ln (u)=-\gamma-\ln \left(\frac{r^{2} S}{4 T t}\right)
$$

The expression of the drawdown at time $t$ is defined by the following equation:

$$
\Delta(t)=\frac{Q}{4 \pi T}\left(\ln \mathrm{e}^{-y}-\ln (u)\right)=\frac{Q}{4 \pi T} \ln \left(\frac{\mathrm{e}^{-y}}{u}\right)
$$


By substituting $\mu$ and $\gamma$ by their respective expression in the previous equation, we get the equality known as the Jacob's equation:

$$
\Delta(t)=\frac{0.183 \times Q}{T} \log _{10}\left(\frac{2.25 T t}{r^{2} S}\right)
$$

Moreover, for the calculation of the hydraulic conductivity, we relied on the cross section (Figure 3 ) and the depth of each borehole tested (3.71 m in Kamna, $1.99 \mathrm{~m}$ in Lah-Gwi and $1.00 \mathrm{~m}$ in Badiangseu).

The characterization of the watershed was made geometrically and morphometrically. In Equations (9)-(11), $\mathrm{Kg}$ is the Gravelus Index, $A$ is the area of the watershed, Leq and leq are the equivalent length and width respectively of the equivalent rectangle of the watershed and $P$ is the perimeter of the watershed [36].

$$
\begin{gathered}
K g=\frac{P}{2 \sqrt{\pi A}} \cong \frac{0.281 \times P}{\sqrt{ } A} \\
\text { Leq }=\frac{K g \sqrt{A}}{1.12 \times\left[1+\sqrt{1-\left(\frac{1.12}{K g}\right)^{2}}\right]} \\
\text { leq }=\frac{A}{\text { Leq }}
\end{gathered}
$$

The piezometric map is produced by Surfer software. The interpolation method used is kriging because it is very often more precise than the other methods [37].

The calculation of the protection zones of water resource were computed using Equation (12) according to Hofmann and Lillich in [38]. In this, $P Z$ is the protection zone; $t$ is the residence time in days already defined by the author ( 1 , $5,10,30,50$ and 90 days); $k$, the effective velocity in $\mathrm{m} /$ day; $n_{e}$, the effective porosity (deduced from the abacus of [39]) and $i$, the hydraulic gradient (determined from the piezometric map) allowed the calculation of the protection zones of water resource.

$$
P Z(m)=t \times k \times i / n_{e}
$$

\section{Results}

\subsection{Characteristic of the Watershed}

The characteristic of the studied watershed, which includes the tributaries of Nkong and Ngam rivers whose general flow direction is SW-NE and whose outlet is the Noun River, are presented in Table 1.

Based on ORSTOM (Oversea Office of Technical and Scientifical Research, organisation replaced nowadays by IRD (Research Institute for Development)) classification and specific elevation difference $(D s)$, the watershed belongs to the class R5-R6 which is characterized by a fairly to strong relief. 


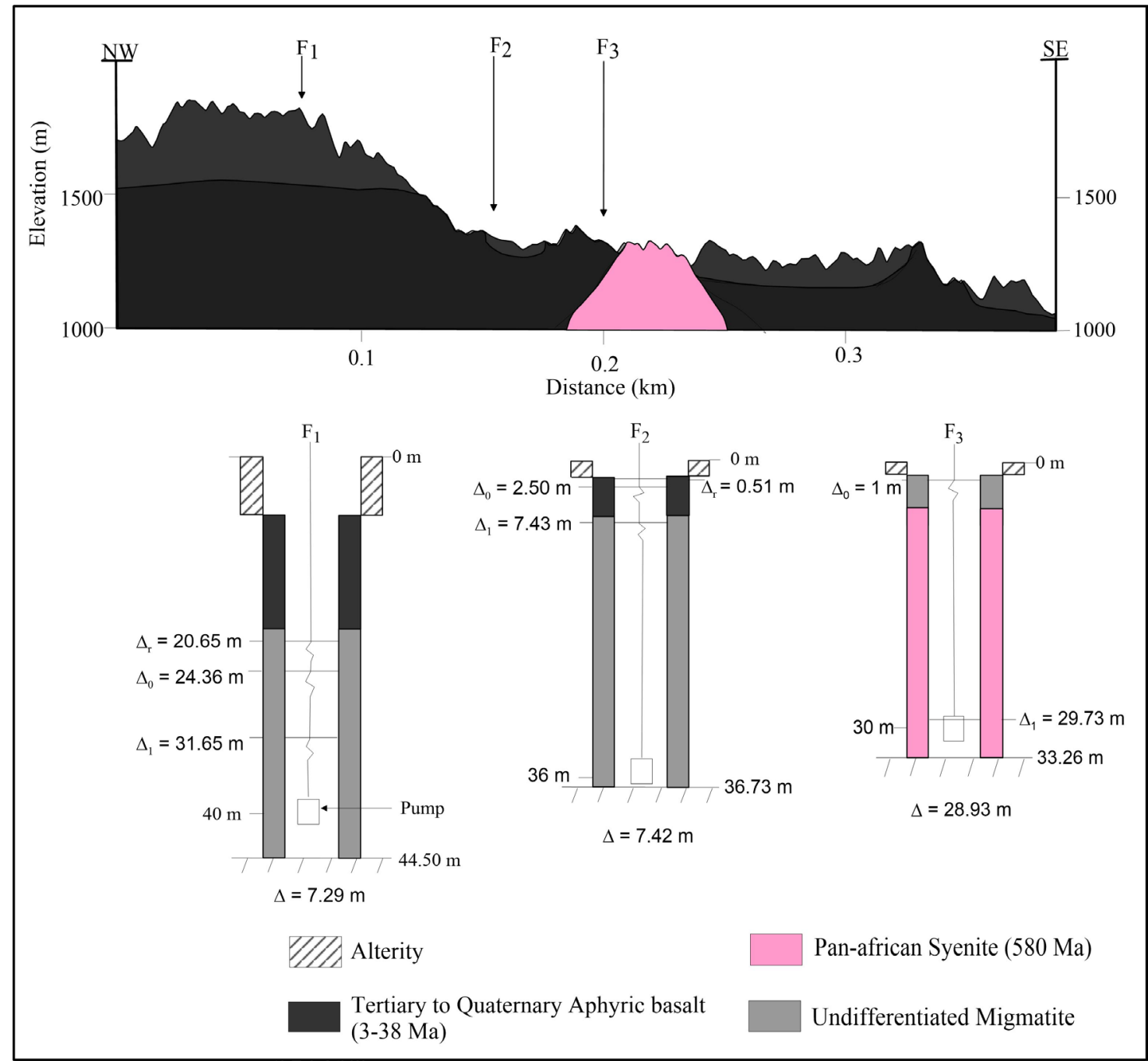

Figure 3. Sketch of the geological cross section of the study area and lithological vertical layers of each borehole.

Table 1. Geometric and morphometric characteristics of the Nkong-Ngam watershed.

\begin{tabular}{ccccccccc}
\hline Sites & $\begin{array}{c}\text { Perimeter } \\
(P \mathrm{~km})\end{array}$ & $\begin{array}{c}\text { Area } \\
\left(A \mathrm{~km}^{2}\right)\end{array}$ & $\begin{array}{c}\text { Gravelus } \\
\text { index }(K g)\end{array}$ & $\begin{array}{c}\text { Rectangle } \\
\text { length }(\text { Leq } \mathrm{km})\end{array}$ & $\begin{array}{c}\text { Maximum } \\
\text { elevation }(\mathrm{m})\end{array}$ & $\begin{array}{c}\text { Minimum } \\
\text { elevation }(\mathrm{m})\end{array}$ & $\begin{array}{c}\text { Average slope Difference in height } \\
(\%)\end{array}$ & $\begin{array}{c}\text { Devation }(D s \mathrm{~m}) \\
\text { elever }\end{array}$ \\
\hline Nkong's watershed & 73.21 & 166.7 & 1.60 & 31.27 & 1898 & 929 & 0.03 & 271.1 \\
Ngam's watershed & 73.98 & 159.6 & 1.64 & 32.00 & 1621 & 900 & 0.11 & 157.9 \\
\hline
\end{tabular}

\subsection{Hydrological Balance}

The results obtained by applying the method of [35] from the temperature and rainfalls data are presented in Table 2.

$8.4 \%$ of rainfall infiltrate to contribute to the groundwater recharge while $55.7 \%$ is evaporated out of a total rainfall of $1380.5 \mathrm{~mm}$. $35.9 \%$ constitute the run-off. Moreover, the excess available for run-off is zero at the Bangangté station. From a hydrological point of view, this result shows that during this period, most of the small rivers dry up; for 5 months, the variation in soil reserves $(\Delta R i)$ is zero. Water stocks in the soil are therefore not renewed or are then strongly 
taken up by evapotranspiration which is very strong in this region; from April to December; actual evapotranspiration $(E T R)$ is equal to potential evapotranspiration $(E T P)$.

During these months the recorded rainfall is lower than the ETR.

Table 2. Hydrological balance of the area studied according to the method of [35].

\begin{tabular}{cccccccccccccc}
\hline & March & April & May & June & July & August & September & October & November December & January & February & Total \\
\hline$E T P(\mathrm{~mm})$ & 86.1 & 79.6 & 75.5 & 68.2 & 67.2 & 68.0 & 66.0 & 68.7 & 71.9 & 75.6 & 81.2 & 76.3 & 884.5 \\
$P(\mathrm{~mm})$ & 85.7 & 131.3 & 150.8 & 130.1 & 133.4 & 176.9 & 246.9 & 236.0 & 59.1 & 6.7 & 4.4 & 19.2 & 1380.5 \\
$T\left({ }^{\circ} \mathrm{C}\right)$ & 22.0 & 21.5 & 20.7 & 20.0 & 19.6 & 19.7 & 19.7 & 19.8 & 20.5 & 20.7 & 21.4 & 21.8 & \\
$\operatorname{ETR}(\mathrm{mm})$ & 85.7 & 79.6 & 75.5 & 68.2 & 67.2 & 68.0 & 66.0 & 68.7 & 71.9 & 75.6 & 22.7 & 19.2 & 768.3 \\
$\operatorname{ETP}-E T R(\mathrm{~mm})$ & 0.4 & 0.0 & 0.0 & 0.0 & 0.0 & 0.0 & 0.0 & 0.0 & 0.0 & 0.0 & 58.5 & 57.2 & 116.1 \\
$R i(\mathrm{~mm})$ & 0.0 & 51.6 & 100.0 & 100.0 & 100.0 & 100.0 & 100.0 & 100.0 & 87.2 & 18.3 & 0.0 & 0.0 & -18 \\
$\Delta R i(\mathrm{~mm})$ & 0.0 & 51.6 & 48.4 & 0.0 & 0.0 & 0.0 & 0.0 & 0.0 & -12.8 & -68.9 & -18.3 & 0.0 & 0.0 \\
\hline
\end{tabular}

\subsection{Piezometry}

The water table measurements of the wells and boreholes carried out in September 2019 and February 2020 which are rainy and dry seasons, respectively. The median piezometric head of the study area for wells and boreholes is $1317 \pm 217$ $\mathrm{m}$ with a maximum of $1675 \pm 217 \mathrm{~m}$ and a minimum of $772 \pm 217 \mathrm{~m}$. The median variation between the dry and rainy season in each well and borehole is $1 \pm$ $0.62 \mathrm{~m}$ with a maximum of $2.5 \pm 0.62 \mathrm{~m}$ and a minimum of $0.19 \pm 0.62 \mathrm{~m}$.

Figure 4 shows the evolution of the piezometric head in the study area.

From Figure 4, the following hydrogeological zones are identified:

- The recharge area located to the NW and WSW of the study site is characterized by the divergence of the underground flow. It is the least suitable location for groundwater catchment. This explains the drying up of observed in some water facilities in the villages of Bangoulap for instance;

- The piezometric depressions or storage area with converging underground flow are located in the Center (F2, Lah-Gwi) and SE of the study area. These are suitable areas for the installation of catchment boreholes [40]. However, these storage areas constitute areas with a high risk of pollution because they are formed by water resulting from direct infiltration (transport of pollutants from the surface to underground: migration) and those which propagate from the drainage areas (propagation of pollutants that are not self-purified).

\subsection{Hydraulic Parameters and Intrinsic Pumping Rate of Discontinuous Fractured Aquifers}

The hydraulic parameters assessed are Transmissivity $\left(T\right.$ in $\left.\mathrm{m}^{2} / \mathrm{s}\right)$ and hydraulic conductivity $(K$ in $\mathrm{m} / \mathrm{s})$ meanwhile the intrinsic flow rates are critical $\left(Q_{c}\right)$ and operating $\left(Q_{e x}\right)$ pumping flow rate. The hydraulic parameters and intrinsic flow rate of discontinuous and fractured aquifers are presented in Table 3. 


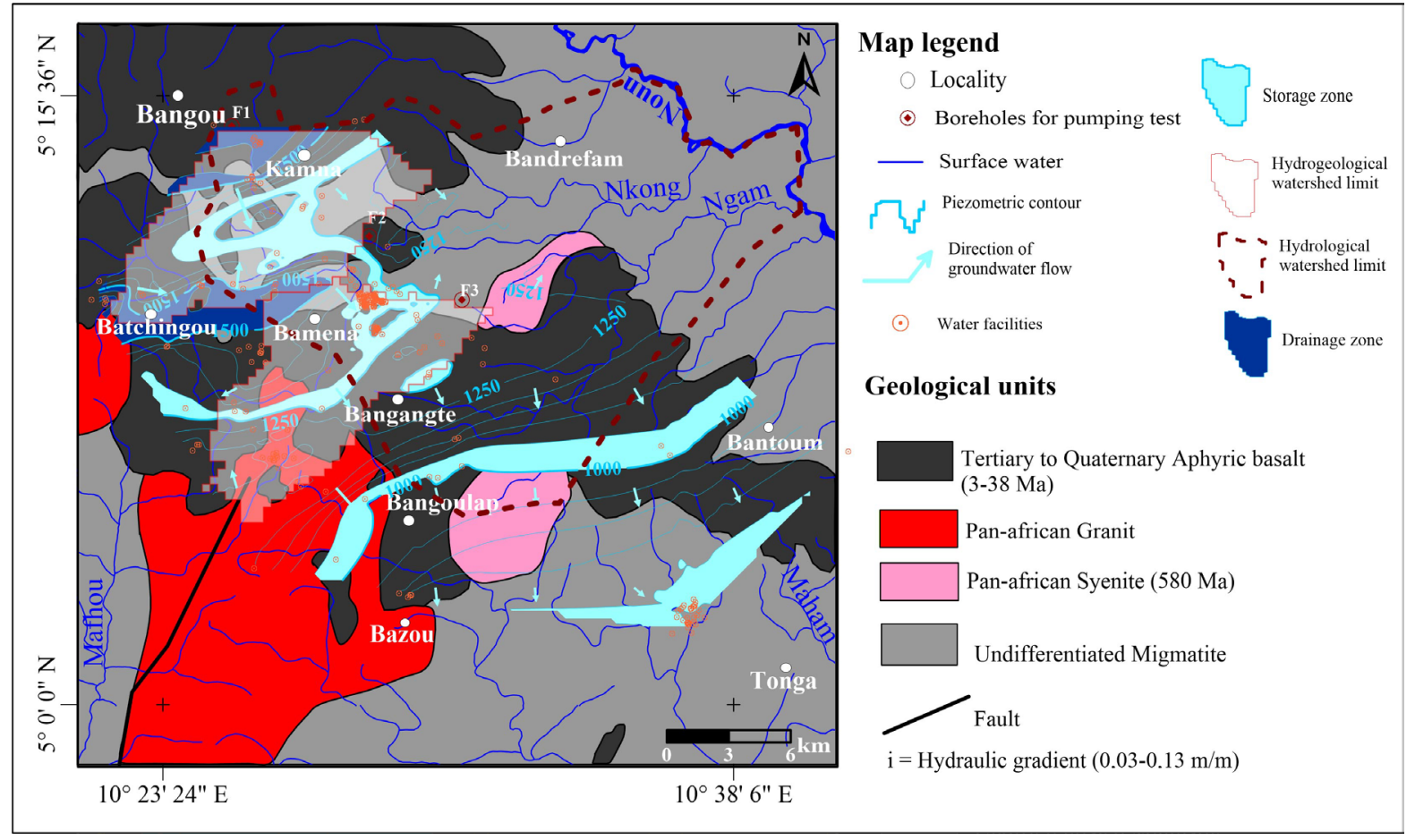

Figure 4. Piezometric map of the study area.

Table 3. Intrinsic pumping rate and hydraulic parameters of basement aquifers in the study area.

\begin{tabular}{|c|c|c|c|}
\hline & Kamna (F1) & Lah-Gwi (F2) & Bandiangseu (F3) \\
\hline Critical pumping rate $\left(Q_{c}\right)$ in $\mathrm{m}^{3} / \mathrm{h}$ & 5 & 10.70 & 2.75 \\
\hline Pumping rate $(Q) \mathrm{m}^{3} / \mathrm{h}$ & 4 & 10 & 1.5 \\
\hline $\begin{array}{l}\text { Operating pumping rate }\left(Q_{e x}\right) \text { in } \\
\mathrm{m}^{3} / \mathrm{h}\end{array}$ & 4.5 & 10.50 & 1.80 \\
\hline Hydraulic conductivity in $\mathrm{m} / \mathrm{s}$ & $4.72 \times 10^{-4}$ & $3.27 \times 10^{-4}$ & $3.33 \times 10^{-4}$ \\
\hline $\begin{array}{l}\text { Transmissivity } T=0.183 \times(Q / C) \\
\text { in } \mathrm{m}^{2} / \mathrm{s}\end{array}$ & $5.65 \times 10^{-5}$ & $3.63 \times 10^{-4}$ & $3.47 \times 10^{-6}$ \\
\hline $\begin{array}{l}\text { Transfer time for a pollutant to } \\
\text { reach aquifer in day }\end{array}$ & 6 & 56 & 3 \\
\hline $\begin{array}{l}\text { Jacob's line equation ( } \Delta \mathrm{s} \text { is the } \\
\text { specific drawdown) }\end{array}$ & $\Delta=1.01 Q+0.19 Q^{2}$ & $\Delta=0.612 Q+0.013 Q^{2}$ & $\Delta=12.86 Q^{2}$ \\
\hline $\begin{array}{l}\text { Recovery after } 12 \text { hours of } \\
\text { continuous pumping }\end{array}$ & $\Delta=7.29 \mathrm{~m}$ & $\Delta=7.42 \mathrm{~m}$ & $\Delta=28.93 \mathrm{~m}$ \\
\hline Intercepted time ti ( $\mathrm{sec})$ & 2500 & 1100 & 90 \\
\hline Pumping reaction time t0 (sec) & 30 & 0.1 & 10 \\
\hline Slope of Jacob's line C & 3.6 & 1.4 & 22 \\
\hline
\end{tabular}

\subsection{Calculation of Water Resource Protection Zone or Radius}

The general hydraulic slope of the Ndé division is more or less steep and implies direct contamination of the water table in the event of accidental pollution of a 
water facility located in a drainage zone. This hydraulic gradient is between 0.03 and $0.13 \mathrm{~m} / \mathrm{m}$ and will help reduce pollutant migration rate into the ground as if $v_{e}=k \times i / n_{e}$ where $k$ is the permeability of the aquifer, $i$ is the hydraulic gradient and $n_{e}$ the effective porosity of the same material, then $v_{e} \ll k$. The protection of groundwater therefore also requires implementation of the protection zones (nearest, closest and farthest radius). Depending on the geographical positions, the choice of catchment borehole for supplying a water network to be rehabilitated will have to be based on the piezometric map established and the geological formation to be captured. The effective porosity $\left(n_{e}\right)$ derived from the chart of [38] in the study area vary between $10 \%-30 \%$. The effective velocity determined by [41] equation $\left(v_{e}=k \times i / n_{e}\right)$ is calculated for each locality in $\mathrm{m} /$ day. The transfer distance in the saturated zone is determined by the method of Hoffmann and Lillich in [39] in which the residence times are set between 1 and 90 days. The results are shown in Table 4.

From Table 4, three protection zones of water resources have been defined [42]:

- The nearest radius (r1): $113-125 \mathrm{~m}$ from the water facility. This radius is useful for direct installations on the water point in order to limit the risks of infiltration of rainwater and wastewater. No pollutant source must be in this radius;

- The closest radius (r2): 125 - $624 \mathrm{~m}$ depending on the piezometric head of the study area. In this area, agricultural activities with enrichment are to be prohibited;

- The farthest radius (r3): $624-1123 \mathrm{~m}$. This radius corresponds to the drainage zones. Pollutant sources must not be there.

These protection zone assimilated to a radius will be implemented on the field as shown in Figure 5.

\section{Le g e n d \\ $\longrightarrow$ Groundwater flow}

Nearest zone r1 (113-125 m)

Closest zone $\mathrm{r} 2$ (125-624 m)

Farthest zone r3 (624-1123 n Fault

Weathered rock

Unweathered rock

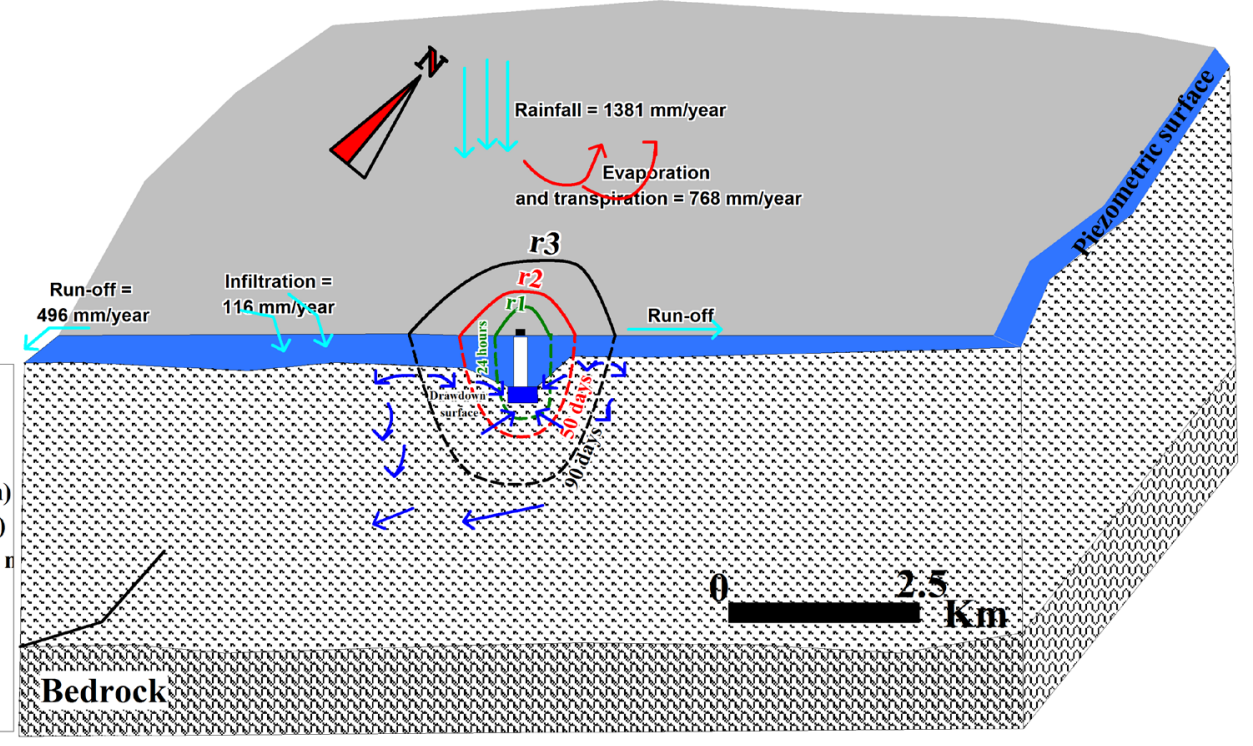

Figure 5. Model for implementing protection zones on the field in the study area. 
Table 4. Protection zones as a radius obtained for the study area.

\begin{tabular}{cccc}
\hline Protection zones & Values in $\mathrm{m}$ & Villages & Effective speed in m/day \\
\hline Nearest & $113-125$ & $\begin{array}{c}\text { Kamna, Toukouop, Sanki, Bangoulap, } \\
\text { Bahouoc and Bamena }\end{array}$ & 12.24 \\
Closest & $125-624$ & Lah-Gwi and Batchingou & 11.33 \\
Farthest & $624-1123$ & Bandiangseu & 12.48 \\
\hline
\end{tabular}

\section{Discussion}

\subsection{Piezometry, Groundwater Recharge and Productivity}

The piezometric map of the study area permits to understand the mode of drainage and recharge of aquifers. This analysis of the morphology of the piezometric surface in the hydrogeological catchment area shows that the piezometric surface intersects the hydrographic network indifferently and the underground flow are not parallel everywhere to the Nkong and Ngam streams. In addition, the main drainage axis of the water table oriented NW-SE, is different from the W-E and WSW-ENE trending rivers flow, which suggests a complex hydraulic connection. These recharge zones identified by the piezometric analysis in the high elevation zones of the watershed are consistent with the functioning of aquifers in the basement area [43] [44] [45] [46] [47].

Moreover, closed piezometric contours are suitable areas for installing water facilities. However, this configuration can reflect the impact of water withdrawals by the population and therefore an interpolation biased by the water table non-steady state [48] and errors due to the absence of precise levelling.

Infiltration data from the water balance combined with the interpretation of piezometric map suggest that the aquifer is recharged by infiltration of effective rainfall [49] in a general case based on the assumptions of [35] [50]. Indeed, the water balance according to [35] method allows to estimate that the infiltration interpreted here as potential recharge would represent $8.4 \%$ of the average annual rainfall. Recharge rates of $9 \%-16 \%$ have been estimated in granite formations at Galicia-Costa in Spain [51]. This dependence of effective infiltration on rainfall has been recognized in other parts of the world (e.g. [52] [53]). This value of infiltration obtained in the study area is greater than those obtained in the basement aquifers of the city of Yaoundé (5.7\%) [9] and lower than that (12\%) obtained in Bongouanou (East of Ivory-Coast) [54]. The difference between these values could be mainly related to differences in climate whose impact on groundwater recharge would be exacerbated by the different geology, soil, vegetation cover and topographic slope in the regions.

The most important transmissivities and hydraulic conductivities are found on volcanic rocks [55]. These results are similar to those obtained in the highlands of West Cameroon which confirm the high productivity of volcanic formations with respect to metamorphic zones [56]. Indeed, [8] also confirm the less productivity of metamorphic aquifer of Yaoundé (Cameroon). The factors that would govern the productivity of boreholes in basement areas are the in- 
trinsic parameters of the aquifer such as transmissivity $(T)$, operating pumping rate $\left(Q_{e x}\right)$ and specific drawdown $(\Delta / Q)$ or specific capacity $(Q / \Delta)$. Indeed, these parameters are directly linked to the nature of the aquifer studied and therefore, the aquifers with the highest values of transmissivities could be the most productive.

Empirical power equations between $Q / \Delta$ and $T$ in varying hydrogeologic settings are proposed by [4]. Considering empirical Equations (13) of [57] cited in [58] and Equation (14) of [59], the transmissivity of the study area was assessed considering the geological formation (volcanic and metamorphic, see Table 5).

$$
\begin{gathered}
T=0.45 \times(Q / \Delta)^{1.05} \quad \text { (Volcanic) } \\
T=0.78 \times(Q / \Delta)^{1.02} \quad \text { (Weakly metamorphosed sedimentary rocks) }
\end{gathered}
$$

From Table 5, transmissivities are in order of $10^{-4}$ to $10^{-5} \mathrm{~m}^{2} / \mathrm{sec}$ when applying the empirical Equations (13) and (14). These results are not too different from those obtained with the method used for this study. Nevertheless, an aquifer with a high value of transmissivity is the more productive [3] and the upper part of a fractured aquifer is also more productive [54]. Furthermore, the productivity is not related to the depth of a borehole [60].

Table 5. Hydraulic parameters of basement aquifers in the study area according to [57] and [59].

\begin{tabular}{ccccccc}
\hline & $C$ & $Q\left(\mathrm{~m}^{3} / \mathrm{h}\right)$ & $\Delta(\mathrm{m})$ & $Q / \Delta\left(\mathrm{m}^{3} / \mathrm{h} / \mathrm{m}\right)$ & $T\left(\mathrm{~m}^{2} / \mathrm{h}\right)$ & $T\left(\mathrm{~m}^{2} / \mathrm{s}\right)$ \\
\hline Kamna (F1) & 0.45 & 4 & 7.29 & 0.55 & $2.40 \times 10^{-1}$ & $6.66 \times 10^{-5}$ \\
Lah-Gwi (F2) & 0.45 & 10 & 7.42 & 1.35 & $6.16 \times 10^{-1}$ & $1.71 \times 10^{-4}$ \\
Bandiangseu (F3) & 0.78 & 1.5 & 28.93 & 0.052 & $3.81 \times 10^{-2}$ & $1.06 \times 10^{-5}$ \\
\hline
\end{tabular}

\subsection{Groundwater Protection}

The hydraulic gradient is variable $\left(3-13 \times 10^{-2}\right)$ and consistent with the heterogeneity of the geological formations. The hydraulic parameters estimated by pumping tests confirm the aquifer character of the geological formations [40], and highlight their hydrodynamic heterogeneity in connection with the differential weathering, the intensity of the fracturing and their well-known probable interconnection in the crystalline basement aquifer [61] [62]. A hydrogeological watershed has been identified in the study area. The main drainage axis is oriented NW-SE. The hydraulic conductivity of the saturated zone is of the order of $10^{-4}$ $\mathrm{m} / \mathrm{s}$, which gives it the term, according to [40], of aquifer and not of aquiclude or aquitard. Based on the classification of water tables by [63], and on the piezometric criterion, the aquifer of the Nkong-Ngam watershed is an unconfined aquifer. With regard to the type of recharge described above, it therefore becomes important to define the protection zones of the water resource in such a heterogeneous aquifer.

Few authors propose, after an inventory of the habitat in the Anga'a and 
Mingoa watersheds in Yaoundé (Cameroon), an appropriate approach for the design of protection zones adapted to urban context [64] [65] The values of the protection radius estimated in this study are very variable and evidences the vulnerability of the aquifer of the Nkong-Ngam watershed. The values $(113,624$ and $1123 \mathrm{~m}$ ) of the protection zones obtained are greater than those obtained by [64] in the urbanized watershed of the Mingoa (10, 15 and $30 \mathrm{~m}$ ) in Yaoundé (Cameroon). This difference is likely linked to the geological context of the study sites.

\section{Conclusions}

The results of this study combined with previous data from the literature allow to draw the followings remarks:

- The water balance shows a recharge rate of $8.4 \%(\approx 116 \mathrm{~mm} /$ year $)$ from a total rainfall of $1380.5 \mathrm{~mm}$ for the period 1951-2016 and it emerges that for three months per year (from January to March), the excess available for run-off is null at the Bangangte station and for 5 months, the variation in soil storage is null. Water stocks in the soil are therefore not renewed or are then strongly taken up by evapotranspiration which is very strong in this region. In addition, from April to December; actual evapotranspiration is equal to potential evapotranspiration.

- The basement aquifer of Ndé division has, on the one hand, a high productivity on volcanic formations $\left(4.5 \leq Q \leq 10.5 \mathrm{~m}^{3} / \mathrm{h}\right)$, but on the other hand has also a very low productivity in metamorphic formations $\left(Q \leq 1.5 \mathrm{~m}^{3} / \mathrm{h}\right)$. Furthermore, hydraulic conductivity of aquifer is in order of $10^{-4} \mathrm{~m} / \mathrm{sec}$ and transmissivity varies from $10^{-4}$ to $10^{-6} \mathrm{~m}^{2} / \mathrm{sec}$. Three hydraulic parameters control the productivity of this basement aquifer: transmissivity, specific drawdown and pumping rate; and this productivity is not related to the depth of the borehole. Empirical equation used to check transmissivities values of aquifer in Ndé Division corroborate with the present results and confirms the fact that, transmissivity is the most important parameter which controls the productivity of aquifers.

Piezometric map confirms that storage areas are suitable for realising catchment water facilities with a high productivity. However, these areas are also exposed to a high vulnerability if protection zones are not implemented. As for the exposure of aquifer to pollutant whose time of transfer varies from 3 to 56 days depending on rock types and hydraulic gradient $(0.03-0.13 \mathrm{~m} / \mathrm{m})$, three protection zones ( $1, \mathrm{r} 2$ and $\mathrm{r} 3$ ) have been proposed for a better protection of this aquifer, respectively 113, 624 and $1123 \mathrm{~m}$ from the centre of the water facilities. All these preliminary data will help for future hydrogeological modelization with "Modflow and model muse" of this aquifer.

\section{Acknowledgements}

The authors thank the Water Authority of the Municipality of Bangangté and 
Environment Research Action in Cameroon (ERA-Cameroun) for their logistic support for the fieldwork and the Delegation of Agriculture and Rural Development of Ndé Division for the collection of hydroclimatic data and the measurement of water table in water facilities. Furthermore, anonymous reviewers are thanked for their very helpful remarks and useful comments.

\section{Conflicts of Interest}

The authors declare no conflict of interest. The funders have no role in the design of the study; in the collection, analysis, or interpretation of the data; in writing the manuscript, or in the decision to publish the results.

\section{References}

[1] Anomohanran, O. (2014) Hydrogeophysical Investigation of Aquifer Properties and Lithological Strata in Abraka, Nigeria. African Earth Sciences, 102, 247-253. https://doi.org/10.1016/j.jafrearsci.2014.10.006

[2] Asfahani, J. (2016) Hydraulic Parameters Estimation by Using an Approach Based On Vertical Electrical Soundings (VES) in the Semi-Arid Khanasser Valley Region, Syria. Journal of African Earth Sciences, 117, 196-206.

https://doi.org/10.1016/j.jafrearsci.2016.01.018

[3] Ebong, D.E., Akpan, A.E. and Onwuegbuche, A.A. (2014) Estimation of Geohydraulic Parameters from Fractured Shales and Sandstone Aquifers of Abi (Nigeria) Using Electrical Resistivity and Hydrogeologic Measurements. Journal of African Earth Sciences, 96, 99-109. https://doi.org/10.1016/j.jafrearsci.2014.03.026

[4] Al Farrah, N., Van Camp, M. and Walraevens K. (2013) Deducing Transmissivity from Specific Capacity in the Heterogeneous Upper Aquifer System of Jifarah Plain, NW-Libya. Journal of African Earth Sciences, 85, 12-21. https://doi.org/10.1016/j.jafrearsci.2013.04.004

[5] PNDP (Programme National pour le Développement Participatif) (2018) Mécanisme de contrôle citoyen de l'action publique dans la commune de Bangangté. Rapport d'étude du Programme National pour le Développement Participatif (PNDP) au Cameroun, Cameroun, $84 \mathrm{p}$.

[6] Djeuda Tchapnga, H.B., Tanawa, E. and Ngnikam, E. (2001) L'eau au Cameroun. Tome 1: Approvisionnement en eau potable. Laboratoire Environnement et Sciences de l'Eau (LESEAU), École Nationale Supérieure Polytechnique de Yaoundé. Presses Universitaire de Yaoundé, Yaoundé, 359 p.

[7] Bon, A.F., Ndam Ngoupayou, J.R., Ewodo Mboudou, G. and Ekodeck, G.E. (2016) Caractérisation hydrogéologique des aquifères de socle altéré et fissuré du bassin versant de l'Olézoa à Yaoundé, Cameroun. Revue des sciences de leau, 29, 149-166. https://doi.org/10.7202/1036545ar

[8] EwodoMboudou, G.A., Ombolo, FouepeTakounjou, A., Bon, A.F. and Ekodeck, G.E. (2012) Étude des Paramètres hydrauliques des aquifères de sub-surface du bassin versant de la Mingosso, région de Yaoundé. Révue-Conseil Africain et Malgache pour l'Enseignement Supérieur (CAMES), 13, 123-127.

[9] Fouepe Takounjou, A., NdamNgoupayou, J.R., Riotte, J., Takem, G.E., Mafany, G., Marechal, J.C. and Ekodeck, G.E. (2011) Estimation of Groundwater Recharge of Shallow Aquifer on Humid Environment in Yaounde, Cameroon Using Hybrid Water-Fluctuation and Hydrochemistry Methods. Environmental Earth Sciences, 64, 107-118. https://doi.org/10.1007/s12665-010-0822-x 
[10] Mfonka, Z., Ndam Ngoupayou, J.R., Ndjigui, P.D., Zammouri, M., Kpoumie, A. and Rasolonana, E. (2015) Hydrochimie et potabilité des eaux du bassin versant du Nchi dans le plateau Bamoun (Ouest Cameroun). International Journal of Biological and Chemical Sciences, 9, 2000-2018. https://doi.org/10.4314/ijbcs.v9i4.39

[11] Ntep, F., Kengne, I.M., EwodoMboudou, G.A., Nyochembeng, N. and Ekodeck, G.E. (2014) Influence of Seasonal Dynamics on Groundwater Resources Quality in Semitropical Urban Zone: Case of the Biyeme Upper Stream Catchment (Yaounde, Cameroon). International Journal of Biological and Chemical Sciences, 8, 1319-1335. https://doi.org/10.4314/ijbcs.v8i3.44

[12] Bonsor, H., MacDonald, A., Casey, V., Carter, R. and Wilson, P. (2018) The Need for a Standard Approach to Assessing the Functionality of Rural Community Water Supplies. Hydrogeology Journal, 26, 367-370. https://doi.org/10.1007/s10040-017-1711-0

[13] Hammond, P.A. (2018) Reliable Yields of Public Water-Supply Wells in the Fractured-Rock Aquifers of Central Maryland, USA. Hydrogeology Journal, 26, 333-349. https://doi.org/10.1007/s10040-017-1639-4

[14] Toteu, S.F., Van Schmus, W.R., Penaye, J. and Michard, A. (2001) New U-Pb, and Sm-Nd Data from North-Central Cameroon and Its Bearing on the Pre-Pan-African History of Central Africa. Precambrian Research, 108, 45-73. https://doi.org/10.1016/S0301-9268(00)00149-2

[15] Ngako, V., Affaton, P. and Njonfang, E. (2008) Pan-African Tectonics in Northwestern Cameroon: Implication for the History of Western Gondwan. Gondwana Research, 14, 509-522. https://doi.org/10.1016/j.gr.2008.02.002

[16] Tchouankoue, J.P., Li, X.H., Ngo Belnoun, R.N., Mouafo, L. and Ferreira, V.P. (2016) Timing and Tectonic Implications of the Pan-African Bangangte Syenomonzonite, West Cameroon: Constraints from in-Situ Zircon U-Pb Age and Hf-O Isotopes. Journal of African Earth Sciences, 124, 94-103. https://doi.org/10.1016/j.jafrearsci.2016.09.009

[17] Njiekak, G., Dörr, W., Tchouankoué, J.P. and Zulauf, G. (2008) U-Pb Zircon and Microfabric Data of (Meta) Granitoids of Western Cameroon: Constraints on the Timing of Pluton Emplacement and Deformation in the Pan-African Belt of Central Africa. Lithos, 102, 460-477. https://doi.org/10.1016/j.lithos.2007.07.020

[18] Tchouankoue, J.P., Simeni, W.N.A., Kagou, D.A. and Li, X.H. (2014) ${ }^{40} \mathrm{Ar} /{ }^{39} \mathrm{Ar}$ Dating of Basaltic Dykes Swarm in Western Cameroon: Evidence of Late Paleozoic and Mesozoic Magmatism in the Corridor of the Cameroon Line. Journal of African Earth Sciences, 93, 14-22. https://doi.org/10.1016/j.jafrearsci.2014.01.006

[19] Simeni, W.N.A., Tchaptchet, T.D., Ngo Belnoun, R.N., Tchouankoue, J.P. and Ganwa, A.A. (2017) Structural Relationship between Brittle Deformation and Paleozoic to Mesozoic Basalt Dykes in the Precambrian Basement of the Southern Continental Part of the Cameroon Volcanic Line. International Journal of Geosciences, 8, 318 331. https://doi.org/10.4236/ijg.2017.83016

[20] Deruelle, B., Ngounouno, I. and Demaiffe, D. (2007) The Cameroon Hot Line (CHL): A Unique Example of Active Alkaline Intraplate Structure in Both Oceanic and Continental Lithospheres. Comptes Rendus Geosciences, 339, 589-600. https://doi.org/10.1016/j.crte.2007.07.007

[21] Fosso, J., Ménard, J.J., Bardintzeff, J.M., Wandji, P., Tchoua, F.M. and Bellon, H. (2005) Les laves du mont Bangou: Une Première Manifestation Volcanique éocène, à affinité transitionnelle, de la Ligne du Cameroun. Comptes Rendus Geosciences, 337, 315-325. https://doi.org/10.1016/j.crte.2004.10.014 
[22] Lemdjou, Y.B., Zhang, D., Tchouankoue, J.P., Hu, J., Tchuimenie, N.N.B., Soh, T.L. and Yuan, Y. (2020) Elemental and Sr-Nb-Pb Isotopic Compositions, and K-Ar Ages of Transitional and Alkaline Plateau Basalts from the Eastern Edge of the West Cameroon Highlands (Cameroon Volcanic Line). Lithos, 358-359, Article ID: 105414. https://doi.org/10.1016/j.lithos.2020.105414

[23] Wotchoko, P., Wandji, P., Bardintzeff, J.M. and Bellon, H. (2005) Données pétrologiques et géochronologiques nouvelles sur le volcanisme alcalin néogène à récent de la rive ouest du Noun (plaine du Noun, Ligne du Cameroun). Review of the Bulgarian Geological Society, 66, 97-103.

[24] Wotchoko, P., Tene Djoukam, J.F., Kouankap Nono, G.D., Kouske, P.A., Nkouathio, D.G. and Atenkia Fonkem, S. (2015) Petrographic and Geochemical Characterization of Basalts in Bangangte Area (West Cameroon): Implications on Their Source. Earth Sciences, 4, 266-274.

[25] Marzoli, A., Piccirillo, E.M., Renne, P.R., Bellieni, G., Lacumin, M., Nyobe, J.B. and Tongwa, A.T. (2000) The Cameroon Volcanic Line Revisited: Petrogenesis of Continental Basaltic Magmas from Lithospheric and Asthenospheric Sources. Journal of Petrol, 41, 87-109. https://doi.org/10.1093/petrology/41.1.87

[26] BUCREP (Bureau central des recensements et des études de populations) (2005) Troisième Recensement Général de la Population et de l'Habitat au Cameroun. Vol. 7, Bureau central des recensements et des études de populations (BUCREP) Répertoire actualisé des villages du Cameroun. Rapport publié, 436 p.

[27] Weecksteen, G. (1957) Carte géologique de reconnaissance à l'échelle du 1/500000. Territoire du Cameroun (coupure Douala-Ouest) avec notice explicative. Imprimerie Nationale du Cameroun, $35 \mathrm{p}$.

[28] Dumort, J.C. (1968) Notice explicative sur la feuille Douala-Ouest. Carte géologique de reconnaissance à l'échelle du 1/500.000. ORSTOM, Yaoundé, Paris, 69 p.

[29] Njofang, C. (2007) Éléments en traces dans les sédiments, les sols et les plantes comestibles dans le bassin versant du Noun (Cameroun): Bases pour une gestion géochimique de l'environnement. Thèse de Doctorat 3ème cycle, Université de Yaoundé I, Cameroon, $300 \mathrm{p}$.

[30] Jacob, C.E. (1950) Flow of Ground Water. In: Rouse, H., Ed., Engineering Hydraulics, John Wiley, New York, chapitre 5, 321-386.

[31] Jacob, C.E. (1947) Drawdown Test to Determine Effective Radius of Artesian Well. Transactions American Society of Civil Engineers, 112, 1047-1070.

[32] Jacob, C.E. (1940) On the Flow of Water in an Elastic Artesian Aquifer. Eos, Transactions American Geophysical Union, 21, 574-586. https://doi.org/10.1029/TR021i002p00574

[33] Banton, O. and Bangoy, M.L. (1996) A New Method to Determine Storage Coefficient from Pumping Test Recovery Data. Groundwater, 34, 775-777.

https://doi.org/10.1111/j.1745-6584.1996.tb02069.x

[34] Theis, C.V. (1935) The Relation between the Lowering of Piezometric Surface and the Rate of the Duration of Discharge of Well Using Groundwater Storage. Eos, Transactions American Geophysical Union, 16, 519-524. https://doi.org/10.1029/TR016i002p00519

[35] Thornthwaite, C.W. (1948) An Approach toward a Rational Classification of Climate. Geography Review, 38, 55-94. https://doi.org/10.2307/210739

[36] Thebe, B. (1999) Le bassin versant. Deust Genie Hydrosanitaire. Université de Montpellier; Laboratoire Hydrologie, Centre IRD de Montpellier, 18 p. 
[37] Gratton, Y. (2002) Le Krigeage: La méthode optimale d'interpolation spatiale. Les articles de l'Institut d'Analyse Géographique, Québec.

[38] Lallemand-Barres, and Roux, J.C. (1989) Guide méthodologique d'établissement des périmètres de protection des captages d'eau souterraine destinée à la consommation humaine. No. 19, Bureau de Recherches Géologiques et Minières (BRGM), Orléans, $224 \mathrm{p}$.

[39] Banton, O. and Bangoy, M.L. (1997) Hydrogéologie: Multiscience environnementale des eaux souterraines. Presse de l'Université du Québec/Aupelf (Agence universitaire de la Francophonie), Québec, 460 p.

[40] Castany, G. (1982) Principes et méthodes de l'hydrogéologie. Dunod Éd Bordas, Paris, $236 \mathrm{p}$.

[41] Darcy, H. (1856) Les fontaines publiques de la ville de Dijon. Dalmont, Paris, 305310.

[42] Alcaydé, G. (2000) Protection générale des ressources en eau et périmètres de protection des captages d'alimentation en eau potable. La Houille Blanche, 86, 57-60. https://doi.org/10.1051/lhb/2000060

[43] Nigate, F., Camp, M.V., Yenehun, A., Sewale Belay, A. and Walraevens, K. (2020) Recharge-Discharge Relations of Groundwater in Volcanic Terrain of Semi-Humid Tropical Highlands of Ethiopia: The Case of Infranz Springs, in the Upper Blue Nile. Water, 12, Article No. 853. https://doi.org/10.3390/w12030853

[44] Mfonka, Z., Ndam Ngoupayou, J.R., Kpoumie, A., Ndjigui, P-D., Zammouri, M., Ngouh, A.N., Mouncherou, O.F., Mfochivé, O.F. and Rakotondrabe, F. (2019) Hydrodynamic and Groundwater Vulnerability Assessment of the Shallow Aquifer of the Foumban Locality (Bamoun Plateau, Western-Cameroon). Arabian Journal of Geosciences, 12, Article No. 165. https://doi.org/10.1007/s12517-019-4328-X

[45] Walraevens, K., Vandecasteele, I., Martens, K., Nyssen, J., Moeyersons, J., Gebreyohannes, T., De Smedt, F., Poesen, J., Deckers, J. and Camp, M.V. (2009) Groundwater Recharge and Flow in a Small Mountain Catchment in Northern Ethiopia. $\mathrm{Hy}_{-}$ drological Sciences Journal, 54, 739-753. https://doi.org/10.1623/hysj.54.4.739

[46] Hemmings, B., Gooddy, D., Whitaker, F., Darling, W.G., Jasim, A. and Gottsmann, J. (2015) Groundwater Recharge and Flow on Montserrat, West Indies: Insights from Groundwater Dating. Journal of Hydrology: Regional Studies, 4, 611-622. https://doi.org/10.1016/j.ejrh.2015.08.003

[47] Lachassagne, P. and Wyns, R. (2005) Aquifère du socle: Nouveaux concepts. Application à la prospection et la gestion de la ressource en eau. Géosciences, 2, 32-37.

[48] Ouedraogo, M. (2016) Caractérisation des aquifères de socle pour l'amélioration de la productivité des forages d'hydraulique villageoise dans le bassin versant du Bandama blanc amont (Nord de la Côte d'Ivoire) (Characterization of Basementaquifers for Improving the Productivity of Boreholes in the Bandama Blanc Watershed (North of IvoryCoast). Géophysique (physics.geo-ph). Université Paris Saclay (ComUE), Paris, 2016SACLS442ff. fftel-02100659v2.

[49] Castany, G. (1963) Traité pratique des eaux souterraines. 2ème édition, 410 figures, Dunod, Paris, 696 p.

[50] Turc, L. (1961) Évolution des besoins en eau d'irrigation. Évapotranspiration potentielle. Formule climatique simplifiée et mise à jour. Annuaire Agronomie, 12, 13 49.

[51] Molinero, J. and Raposo, J. (2007) Recharge Estimation and Groundwater Resources Assessment in Granitic Terrains of Galicia-Costa Hydrographical District (NW Spain). 
35th IAH Congress-Groundwater and Ecosystems, Lisbon, 17-21 September 2007, 221-222.

[52] Feumba, R., Ngounou Ngatcha, B., Tabué Youmbi, J.G. and Ekodeck, G.E. (2011) Relationship between Climate and Groundwater Recharge in the Besseke Watershed (Douala-Cameroon). Journal of Water Resource and Protection, 3, 607-619. https://doi.org/10.4236/jwarp.2011.38070

[53] Kili, M., Bouabid, E.M. and Jamal, C. (2008) Bilan hydrique des sols et recharge de la nappe profonde de la plaine du Gharb (Maroc). Sécheresse, 19, 145-151.

[54] Assemian, EA., Kouamé, F.K., Saley, M.B., Affian, K., Youan, Ta M., Jourda, J.R. and Biemi, J. (2014) Étude de la productivité d'un aquifère de socle et approche statistique pour la détermination des tranches de profondeurs potentiellement productives: cas de la région de Bongouanou, est de la Côte d'Ivoire. Revue des sciences de P eaul Journal of Water Science, 27, 81-97. https://doi.org/10.7202/1021984ar

[55] Lachassagne, P. and Maréchal, J.C. (2004) Synthèse des concepts et méthodes de l'hydrogéologie des milieux volcaniques appliqués à la prospection géothermique. Études réalisées dans le cadre du projet de recherche Géothermie Haute enthalpie dans les DOM (GHEDOM)-ENER-04 et suivant la convention n 0205035 établie entre le BRGM et l'ADEME; Rapport final BRGM/RP-53135-FR; octobre 2004; 79 p.

[56] Nono, A., Likeng, J.D.H., Wabo, H., Tabue Youmbi, J.G. and Biaya, S. (2009) Influence de la nature lithologique et des structures géologiques sur la qualité et la dynamique des eaux souterraines dans les hauts plateaux de l'Ouest-Cameroun. International Journal of Biological and Chemical Sciences, 3, 218-239.

http://www.ajol.info https://doi.org/10.4314/ijbcs.v3i2.44516

[57] Choi, B.S. (1999) Determination of Aquifer Characteristics from Specific Capacity Data of Wells in Cheju Island. Journal of Korean Society on Groundwater Environment, 6, 180-187. (in Korean)

[58] Hamm, S.Y., Cheong, J.Y., Jang, S., Jung, C.Y. and Kim, B.S. (2005) Relationship between Transmissivity and Specific Capacity in the Volcanic Aquifers of Jeju Island. Korea. Hydrogeology Journal, 13, 111-121. https://doi.org/10.1016/j.jhydrol.2004.12.006

[59] Acheampong, S.Y. and Hess, J.W. (1998) Hydrogeologic and Hydrochemical Framework of the Shallow Groundwater System in the Southern Voltaian Sedimentary Basin of Ghana. Hydrogeology Journal, 6, 527-537. https://doi.org/10.1007/s100400050173

[60] Ble, O.L., Ake Soro, T., Etienne, G., Ahoussi Kouassi, E., Oga, M.S., Jean Biémi, J. and Akossi, D. (2015) Productivity of Water Wells in Crystalline and Crystallophyllian Environment in Daoukro Region (Center-East of the Ivory Coast). Synthèse: Revue des Sciences et de la Technologie, 30, 76-90.

[61] Wyns, R. (2002) Climat, eustatisme, tectonique: Quels contrôles pour l'altération continentale? Exemple des séquences d'altération cénozoïques en France. Bulletin d'Information des Géologues du Bassin de Paris, 39, 5-16.

[62] Wright, E.P. and Burgess, W.G. (1992) Hydrogeology of Crystalline Basement Aquifers in Africa. Geological Society, London, Special Publications, 66, 1-27. https://doi.org/10.1144/GSL.SP.1992.066.01.01

[63] Schoeller, H. (1962) Les eaux souterraines: Hydrologie dynamique et statique. Comptes rendus critiques. 699. Hydrogéologie en chambre Paris, Masson, in- $8^{\circ}, 187$ fig. NF $105,642 \mathrm{p}$

[64] Tabué Youmbi, J.G., Ntamack, D., Feumba, R., Ngnikam, E., Wethé, J. and Tanawa, 
E. (2009) Vulnérabilité des eaux souterraines et Périmètres de protection dans un bassin versant de la Mingoa (Yaoundé, Cameroun). Revue de I Université de Moncton, 40, 71-96. https://doi.org/10.7202/1001389ar

[65] Djeuda Tchapnga, H.B., Tanawa, E., Siakeu, J. and Ngnikam, E. (1998) Contraintes sociales liées à la mise en place des périmètres de protection des ressources en eau dans les zones périurbaines et les petits centres des pays développement. Communication présentée au 2ème symposium international en gestion et technologies appropriées pour P eau aux petits ensembles habités. Barcelone (Espagne), Du 13 au 15 octobre 1998, $11 \mathrm{p}$. 